\title{
Tryptophan Metabolism in Man *
}

\author{
Alfred F. Michael, $\dagger$ Keith N. Drummond, Doris Doeden, John A. \\ ANDERSON, AND ROBERT A. GoOD $\ddagger$ \\ (From the Pediatrics Research Laboratories, Variety Club Heart Hospital, and the Department \\ of Pediatrics, University of Minnesota, Minneapolis, Minn.)
}

The amino acid tryptophan is unique because it contains the indole nucleus and because it is metabolized in man through several different biochemical pathways to a number of specific products. It is the precursor of serotonin and 5-hydroxyindoleacetic acid. In addition, after cleavage of the indole ring, it may be metabolized by way of the kynurenine pathway to 3-hydroxyanthranilic acid and ultimately to nicotinamide. In mammalian liver the benzene ring is oxidized and metabolized through a number of intermediate reactions to glutarate, acetate, and carbon dioxide $(1,2)$. Tryptophan is also the precursor of indolic acids, such as 3 -indoleacetic acid. In man this compound is formed both by tissue enzymes and by bacteria in the gut (3). In the intestinal tract, bacteria that contain tryptophanase (4) reductively cleave the side chain of tryptophan and form indole, which is absorbed, conjugated in the liver, and excreted as indican (sulfated potassium ester of indoxyl). In addition to the various reactions involving the indole ring or side chain, tryptophan, like other amino acids, is incorporated into protein. These pathways are schematically shown in Figure 1.

The many different enzyme systems and important cofactors, such as pyridoxal phosphate, that take part in these reactions have been ably reviewed (5-7) and will not be discussed here. In the investigation of tryptophan metabolism in man, a number of variables must be considered. These include not only these enzymes and cofactors, but

\footnotetext{
* Submitted for publication March 3, 1964 ; accepted May 12, 1964.

Aided by grants from the U. S. Public Health Service (HE-06314 and HE-05662), the National Foundation, American Heart Association, Minnesota Heart Association, and the Graduate School of the University of Minnesota.

† Established Investigator, American Heart Association.

¥American Legion Memorial Heart Research Professor of Pediatrics and Microbiology.
}

also factors such as the adequacy of intestinal absorption of tryptophan, the age, sex, and nutrition of the subject (8), and the amount of tryptophan administered. Although abnormalities in tryptophan metabolism have been described in a number of disease states $(6,7,9-19)$, the significance of these observations has often been difficult to explain or understand. Part of this difficulty may be related to an inadequate assessment of these variables. Obviously the recognition of an abnormality must first depend upon comparison with adequate data obtained from normal individuals. Ideally, such an evaluation should include representative metabolites of each of the major pathways.

The purposes of this paper are 1) to present kinetic and quantitative data on the urinary excretion of 13 tryptophan metabolites in children and adults, and 2) to describe metabolic differences that exist between normal adult females and adult males or children. This method of analysis has been used in describing the biochemical abnormalities of a disease characterized by failure of intestinal transport of tryptophan, indicanuria, and hypercalcemia $(20,21)$; it may also be useful in understanding other diseases in which there is altered tryptophan metabolism.

\section{Materials and Methods}

Investigations were carried out on ten Caucasian prepubertal children (group I) who were hospitalized on the pediatric wards of the University of Minnesota Hospitals. None of these children had diseases associated with known abnormalities of tryptophan metabolism: five were essentially well and normal; four were receiving physical therapy and orthopedic assistance because of isolated joint contractures secondary to poliomyelitis, dislocated hip, and burn scar; and one patient had residual rheumatic mitral valvular disease. Complete studies were also performed on 16 normal Caucasian adults, consisting of eight females (group II) and eight males (group III). Group IV consisted of nine adult females and two adult males. In this latter group, 


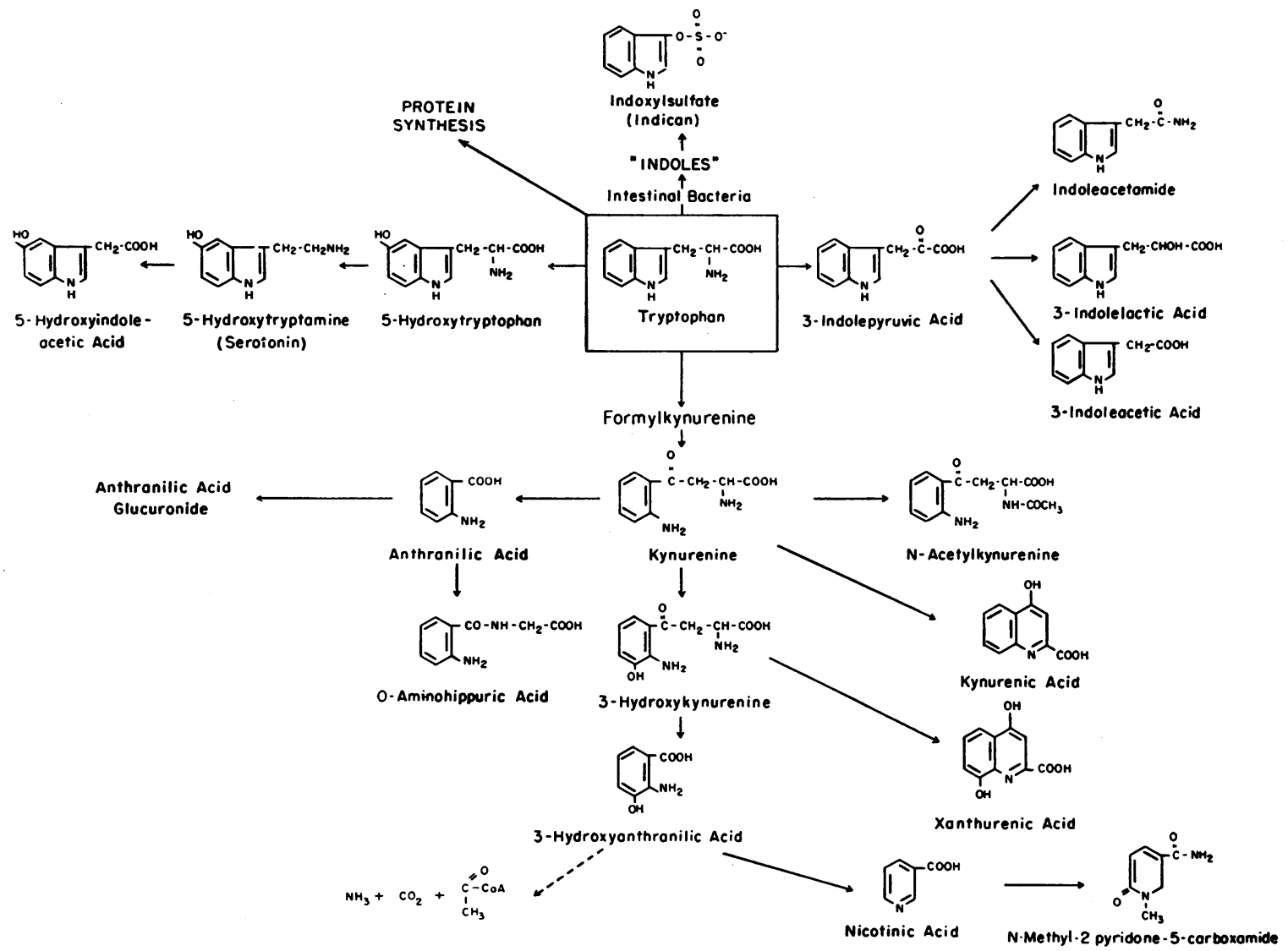

Fig. 1. Metabolic path Ways of tryptophan.

the only biochemical determinations performed were for urinary kynurenine and acetylkynurenine. The subjects in groups II to IV were normal medical students, laboratory technicians, or volunteers. The sex, age, and weight of the children and adults are summarized in Table $I$. The dietary intake was not restricted and consisted of standard hospital food for the children, and for the adults a normal diet that did not contain bananas or nuts. The tryptophan was given in the morning after an overnight fast; the subjects were then permitted to have their usual noonday and evening meals. No supplemental vitamins or drugs were administered preceding or during the period of investigation.

In children urine was collected in periods of 4 to 6

TABLE I

Distribution of control subjects given tryptophan loads

\begin{tabular}{|c|c|c|c|c|c|c|}
\hline \multirow[b]{2}{*}{ Group } & \multirow[b]{2}{*}{ Age range } & \multirow[b]{2}{*}{ Weight range } & \multirow{2}{*}{$\begin{array}{l}\text { No. and sex } \\
\text { of subjects }\end{array}$} & \multicolumn{2}{|c|}{$\begin{array}{l}\text { Tryptophan administration } \\
\text { and dose }\end{array}$} & \multirow[b]{2}{*}{ Metabolites measured } \\
\hline & & & & Oral & iv & \\
\hline I & $\cdot 11^{\text {years }}$ mo-12* & $\begin{array}{c}k g \\
8.0-50.0\end{array}$ & $5 \mathrm{M}, 5 \mathrm{~F}$ & $\begin{array}{c}m g / k g \\
100\end{array}$ & $\begin{array}{c}m g / k g \\
100(3)\end{array}$ & All \\
\hline II & $18-43$ & $50.0-75.4$ & $8 \mathrm{~F}$ & $100(6) \dagger$ & & All \\
\hline III & $23-32$ & $75.0-85.9$ & $8 \mathrm{M}$ & 100 & & All \\
\hline \multirow[t]{2}{*}{ IV } & $23-47$ & $58.2-90.4$ & $9 \mathrm{~F}, 2 \mathrm{M}$ & $\begin{array}{c}100 \\
(2 \mathrm{M}, 3 \mathrm{~F})\end{array}$ & & Kynurenine and acetylkynurenine \\
\hline & & & & $\begin{array}{l}58-87 \\
(6 \mathrm{~F})\end{array}$ & & \\
\hline
\end{tabular}

* The ages of the children in years were as follows: 11 months and $3,4,5,6,8,9,10,11$, and 12 years.

$\dagger$ Two females in this group were not given a tryptophan load of $100 \mathrm{mg}$ per $\mathrm{kg}$, and therefore postload data are available for six members only. 
hours for 24 hours preceding and 24 hours after the tryptophan load. In adult subjects, urine was collected in 6-, 8-, or 24-hour intervals for 24 hours before and 24 hours after oral tryptophan. Specimens were kept on ice without preservative during the period of collection and were then kept at $-20^{\circ} \mathrm{C}$ until analyzed.

L-Tryptophan ${ }^{1}$ was administered orally in a powdered form in milk or fruit juice in doses as noted in Table I. In three children the tryptophan was given with a carmine marker so that the stool could be examined for tryptophan. Random stool specimens were also obtained for the same purpose from seven normal subjects. In three children (S.N., S.S., K.L.) tryptophan was administered intravenously, in a dose identical to the oral dose, in a solution containing $500 \mathrm{mg}$ of L-tryptophan in $100 \mathrm{ml}$ of pyrogen-free distilled water. Sodium bisulfite was added to a concentration of $0.050 \mathrm{~g}$ per 100 $\mathrm{ml}$ to prevent degradation of tryptophan during autoclaving. The solution had a $\mathrm{pH}$ of 5.50 and was shown to be pyrogen-free by injection into rabbits and monkeys. Two-dimensional paper chromatography for indoles (22) revealed no indolic compounds except tryptophan. The solution was mixed with an appropriate volume of $50 \%$ glucose solution to a final concentration of $5 \mathrm{~g}$ of glucose per $100 \mathrm{ml}$ and administered intravenously over a period of 4 hours. Two to 3 days elapsed between the oral and subsequent intravenous load.

A similar investigation has been performed on a patient with familial hypercalcemia of infancy associated with tryptophan malabsorption, indicanuria, and blue diapers $(20,21)$.

In 14 subjects serum calcium was determined, by EDTA titration using calcein as an indicator, at 4- to 12-hour intervals before and after tryptophan administration. The normal values in this laboratory are 9.0 to $10.5 \mathrm{mg}$ per $100 \mathrm{ml}$.

Biochemical methods. Acetylkynurenine, kynurenine, anthranilic acid, anthranilic glucuronide, and o-aminohippuric acid were determined by the elution column chromatographic methods of Brown and Price (23). The columns were prepared with Dowex $50 \mathrm{~W}-\mathrm{X} 12$ (200 to 400 mesh) and were first washed with $80 \mathrm{ml}$ of $8.0 \mathrm{~N}$ hydrochloric acid followed by $200 \mathrm{ml}$ of distilled water and then $25 \mathrm{ml}$ of $0.1 \mathrm{~N}$ hydrochloric acid as recommended by Tompsett (24).

All urine samples were analyzed in duplicate by diluting 10 to $30 \mathrm{ml}$ of the pretryptophan urine specimens and 2 to $10 \mathrm{ml}$ of postload samples to a volume of 40 $\mathrm{ml}$ and a final hydrochloric acid concentration of $0.10 \mathrm{~N}$. In each instance a recovery control was also prepared by adding 250 to $500 \mu \mathrm{g}$ of each metabolite ${ }^{2}$ to a similar

1 Obtained from Nutritional Biochemicals Corp., Cleveland, Ohio.

${ }^{2}$ Kynurenine, kynurenic acid, xanthurenic acid, 3-hydroxyanthranilic acid, and indole-3-acetic acid were obtained from Nutritional Biochemicals Corp., Cleveland, Ohio; anthranilic acid from Eastman Organic Chemicals, Rochester, N. Y.; 3-hydroxykynurenine from Mann Research Laboratories, New York, N. Y.; N-methyl-2- volume of the urine specimen. In most instances, the recoveries of the various metabolites were between 85 and $105 \%$. The diluted sample was then applied to the column and allowed to drip through at a rate of 8 drops per minute. This was followed by $40 \mathrm{ml}$ of $0.10 \mathrm{~N}$ hydrochloric acid, and both $0.10 \mathrm{~N}$ hydrochloric acid eluates were combined. The column was then eluted stepwise with $80 \mathrm{ml}$ each of $0.5,1.0,2.4$, and $5.0 \mathrm{~N}$ hydrochloric acid. The colorimetric determination of the diazotizable amines present in the various fractions was performed according to the method of Brown and Price (23).

3-Hydroxykynurenine was determined in the $5.0 \mathrm{~N}$ hydrochloric acid eluate as described by Brown (25). In five urine samples the determination of this compound was also carried out by the method of Tompsett (24) ; the results were found to agree with the method of Brown within 5.1 to $8.3 \%$. The determination of 3-hydroxyanthranilic acid by the column chromatographic method has not been previously reported. Although Tompsett (24) states that this metabolite is present in the $1.0 \mathrm{~N}$ hydrochloric acid eluate, it has been detected consistently in the $2.4 \mathrm{~N}$ eluate in this laboratory. The determination is carried out with the color reaction that develops after the addition of $0.25 \%$ sodium nitrite and $10 \%$ ammonium sulfamate as described in the method for 3-hydroxykynurenine. The results agree closely with the colorimetric method of Tompsett (26) using 2,6dichloroquinone chlorimide. Kynurenic and xanthurenic acids were separated by elution chromatography with Dowex $50 \mathrm{~W}-\mathrm{X} 12$ and measured in an Aminco-Bowman spectrophotofluorometer (27).

3-Indoleacetic acid was determined by the method of Weissbach, King, Sjoerdsma, and Udenfriend (3). The urine sample was hydrolyzed first, so that the determination represents the free and conjugated 3-indoleacetic acids. This method has also been shown to measure indoleacetamide and indolelactic acid (28). No attempt was made to control the urinary $\mathrm{pH}$ or regulate the ratio of free to combined 3-indoleacetic acid. $N$-Methyl-2-pyridone-5-carboxamide ("pyridone") in the urine was determined spectrophotometrically after passage through a layered Dowex column (29). 5-Hydroxyindoleacetic acid (5-HIAA) was determined in the children's urine according to the procedure of Udenfriend, Titus, and Weissbach (30). The data for 5-HIAA are presented separately, since there was an insufficient amount of urine in postload specimens from five of the children to complete the analysis of this compound. Urinary indican was determined according to the method of Meiklejohn and Cohen (31).

Chromatography of urine and stool extracts. Twentyfive $g$ of stool was homogenized in a Waring blendor with $125 \mathrm{ml}$ cold sodium phosphate buffer ( $\mathrm{pH} 5.8$ ). After centrifugation at $2,500 \mathrm{rpm}\left(4^{\circ} \mathrm{C}\right)$ for 2 hours, the supernatant liquid was extracted four times with an pyridone-5-carboxamide from California Corp. for Biochemical Research, Los Angeles, Calif.; 5-hydroxyindoleacetic acid from Aldrich Chemical, Milwaukee, Wis. 
TABLE II

Mean urinary excretion of tryptophan metabolites 24 hours before and 24 hours after oral $L$-tryptophan in ten control children (group I)

\begin{tabular}{|c|c|c|c|c|c|c|c|c|}
\hline \multirow[b]{2}{*}{ 、 } & \multicolumn{2}{|c|}{ Before tryptophan } & \multicolumn{2}{|c|}{ After tryptophan } & \multicolumn{2}{|c|}{ Before tryptophan } & \multicolumn{2}{|c|}{ After tryptophan } \\
\hline & Mean & $\mathrm{SD}^{*}$ & Mean & SD* & Mean & $\mathrm{SD}^{*}$ & Mean & SD* \\
\hline & \multicolumn{4}{|c|}{ Hmoles/24 hours } & \multicolumn{4}{|c|}{ $\mu$ moles $/ 24$ hours $/ \mathrm{kg}$} \\
\hline $\begin{array}{l}\text { Kynurenine } \\
\text { 3-Hydroxykynurenine } \\
\text { 3-Hydroxyanthranilic acid } \\
\text { Anthranilic acid } \ddagger \\
\text { o-Aminohippuric acid } \\
\text { Kynurenic acid } \\
\text { Xanthurenic acid } \\
\text { Pyridones } \\
\text { 3-Indoleacetic acid } \\
\text { Indican }\end{array}$ & $\begin{array}{c}7.55 \\
25.8 \\
36.7 \\
3.47 \\
4.29 \\
8.23 \\
9.99 \\
84.1 \\
38.0 \\
147\end{array}$ & $\begin{array}{l}6.26 \\
13.0 \\
22.4 \\
2.50 \\
2.95 \\
5.89 \\
7.80 \\
90.7 \\
19.4 \\
99.8\end{array}$ & $\begin{array}{c}132 \\
97.7 \\
114 \\
20.6 \\
17.9 \\
100 \\
45.3 \\
226 \\
104 \\
172\end{array}$ & $\begin{array}{c}115 \\
42.7 \\
88.9 \\
18.1 \\
18.1 \\
61.5 \\
23.6 \\
185 \\
78.8 \\
148\end{array}$ & $\begin{array}{l}0.310 \\
1.10 \\
1.54 \\
0.152 \\
0.165 \\
0.289 \\
0.394 \\
4.20 \\
1.68 \\
6.24\end{array}$ & $\begin{array}{l}0.127 \\
0.219 \\
0.54 \\
0.071 \\
0.063 \\
0.155 \\
0.170 \\
4.34 \\
0.756 \\
3.02\end{array}$ & $\begin{array}{l}6.15 \\
4.51 \\
4.73 \\
0.962 \\
0.665 \\
4.08 \\
1.94 \\
9.26 \\
4.09 \\
6.61\end{array}$ & $\begin{array}{l}2.82 \\
1.92 \\
2.13 \\
0.845 \\
0.52 \\
1.25 \\
0.648 \\
5.19 \\
1.06 \\
3.39\end{array}$ \\
\hline
\end{tabular}

* The standard deviation in this and subsequent tables is calculated as follows: $\mathrm{SD}=\sqrt{\frac{\Sigma x^{2}-\frac{(\Sigma x)^{2}}{n}}{n-1}}$

$\dagger$ Kynurenine and acetylkynurenine.

$\ddagger$ Anthranilic acid and anthranilic glucuronide.

equal volume of cold buffered $n$-butanol. The pooled extracts were evaporated to dryness and then dissolved in $10 \mathrm{ml}$ of absolute ethanol. Two-dimensional paper chromatography for indoles using isopropanol/ammonia/ water $(10 / 1 / 2)$ and $n$-butanol/acetic acid/water (12/3/5) was performed on $60 \mu 1$ of the stool extract. Amino acid chromatography was also performed on a similar volume of extract using a two-dimensional system with phenol/ ammonia (200/1) and $n$-butanol/acetic acid/water (12/ 3/5) (22). Urinary indole and amino acid chromatography was carried out in a similar fashion with $50 \mu \mathrm{l}$ of urine for the former and an amount of urine containing $40 \mu \mathrm{g}$ of creatinine for the latter (32). For detection of spots the indole chromatograms were dipped in p-dimethylaminobenzaldehyde (Ehrlich's reagent) or stained with xanthydrol reagent, and the amino acid chromatograms were sprayed with Ninhydrin reagent.

\section{Results}

1) Twenty-four hour urinary excretion of metabolites. The excretion (micromoles per 24 hours) of metabolites in the children, adult males, and adult females 24 hours before and after L-tryptophan is recorded in Tables II to IV. Acetylkynurenine and anthranilic glucuronide were measured separately, but the values for these compounds were combined with those of kynurenine and anthranilic acid, respectively.

TABLE III

Mean urinary excretion of tryptophan metabolites 24 hours before and 24 hours after oral L-tryptophan (100 mg per $\mathrm{kg}$ ) in normal adult females (group II)*

\begin{tabular}{|c|c|c|c|c|c|c|c|c|}
\hline & \multicolumn{2}{|c|}{ Before tryptophan } & \multicolumn{2}{|c|}{ After tryptophan } & \multicolumn{2}{|c|}{ Before tryptophan } & \multicolumn{2}{|c|}{ After tryptophan } \\
\hline & Mean & SD & Mean & SD & Mean & SD & Mean & SD \\
\hline & \multicolumn{4}{|c|}{ $\mu$ moles $/ 24$ hours } & \multicolumn{4}{|c|}{ «moles $/ 24$ hours $/ \mathrm{kg}$} \\
\hline $\begin{array}{l}\text { Kynurenine } \\
\text { 3-Hydroxykynurenine } \\
\text { 3-Hydroxyanthranilic acid } \\
\text { Anthranilic acid } \ddagger \\
\text { o-Aminohippuric acid } \\
\text { Kynurenic acid } \\
\text { Xanthurenic acid } \\
\text { Pyridones } \\
\text { 3-Indoleacetic acid } \\
\text { Indican }\end{array}$ & $\begin{array}{c}16.7 \\
68.7 \\
54.0 \\
14.1 \\
8.22 \\
15.0 \\
18.2 \\
156 \\
82.3 \\
305\end{array}$ & $\begin{array}{c}7.05 \\
44.8 \\
30.9 \\
4.94 \\
3.43 \\
11.8 \\
8.21 \\
92.1 \\
43.1 \\
175\end{array}$ & $\begin{array}{c}1,351 \\
835 \\
383 \\
192 \\
46.9 \\
517 \\
563 \\
321 \\
295 \\
292\end{array}$ & $\begin{array}{l}444 \\
290 \\
115 \\
71 \\
46.3 \\
283 \\
374 \\
260 \\
116 \\
168\end{array}$ & $\begin{array}{l}0.284 \\
1.16 \\
0.890 \\
0.229 \\
0.137 \\
0.246 \\
0.301 \\
2.01 \\
1.31 \\
4.97\end{array}$ & $\begin{array}{l}0.103 \\
0.832 \\
0.486 \\
0.057 \\
0.060 \\
0.194 \\
0.129 \\
1.64 \\
0.542 \\
2.68\end{array}$ & $\begin{array}{l}23.8 \\
14.5 \\
7.00 \\
3.38 \\
0.821 \\
9.01 \\
9.85 \\
5.52 \\
5.20 \\
5.09\end{array}$ & $\begin{array}{l}7.49 \\
3.98 \\
2.34 \\
1.23 \\
0.794 \\
4.59 \\
6.37 \\
3.99 \\
1.95 \\
2.75\end{array}$ \\
\hline
\end{tabular}

* The values recorded before tryptophan loading were obtained from eight women; six of these subjects were given a tryptophan load (100 $\mathrm{mg}$ per $\mathrm{kg}$ ).

$\dagger$ Kynurenine and acetylkynurenine.

$\ddagger$ Anthranilic acid and glucuronide. 
TABLE IV

Mean_urinary excretion of tryptophan metabolites 24 hours before and 24 hours after oral L-tryptophan (100 mg per $\mathrm{kg}$ ) in eight normal adult males (group III)

\begin{tabular}{|c|c|c|c|c|c|c|c|c|}
\hline \multirow[b]{2}{*}{ Metabolite } & \multicolumn{2}{|c|}{ Before tryptophan } & \multicolumn{2}{|c|}{ After tryptophan } & \multicolumn{2}{|c|}{ Before tryptophan } & \multicolumn{2}{|c|}{ After tryptophan } \\
\hline & Mean & SD & Mean & SD & Mean & SD & Mean & SD \\
\hline & \multicolumn{4}{|c|}{ umoles/24 hours } & \multicolumn{4}{|c|}{$\mu$ moles $/ 24$ hours $/ \mathrm{kg}$} \\
\hline $\begin{array}{l}\text { Kynurenine* } \\
\text { 3-Hydroxykynurenine } \\
\text { 3-Hydroxyanthranilic acid } \\
\text { Anthranilic acid† } \\
\text { o-Aminohippuric acid } \\
\text { Kynurenic acid } \\
\text { Xanthurenic acid } \\
\text { Pyridones } \\
\text { 3-Indoleacetic acid } \\
\text { Indican }\end{array}$ & $\begin{array}{l}21.9 \\
78.2 \\
59.8 \\
13.4 \\
12.3 \\
26.4 \\
29.7 \\
117 \\
118 \\
502\end{array}$ & $\begin{array}{c}12.3 \\
24.8 \\
34.9 \\
4.84 \\
5.30 \\
6.51 \\
13.1 \\
69.9 \\
35.6 \\
201\end{array}$ & $\begin{array}{l}643 \\
472 \\
297 \\
135 \\
41.1 \\
379 \\
208 \\
305 \\
439 \\
465\end{array}$ & $\begin{array}{l}503 \\
435 \\
201 \\
77.3 \\
12.0 \\
169 \\
208 \\
126 \\
219 \\
91.2\end{array}$ & $\begin{array}{l}0.275 \\
0.979 \\
0.746 \\
0.166 \\
0.153 \\
0.328 \\
0.327 \\
1.47 \\
1.47 \\
6.29\end{array}$ & $\begin{array}{l}0.161 \\
0.330 \\
0.435 \\
0.063 \\
0.069 \\
0.077 \\
0.210 \\
0.879 \\
0.464 \\
2.64\end{array}$ & $\begin{array}{l}8.07 \\
5.93 \\
3.69 \\
1.69 \\
0.513 \\
4.75 \\
2.60 \\
3.77 \\
5.41 \\
5.81\end{array}$ & $\begin{array}{l}6.28 \\
5.43 \\
2.49 \\
0.973 \\
0.164 \\
2.24 \\
2.57 \\
1.50 \\
2.68 \\
1.26\end{array}$ \\
\hline
\end{tabular}

* Kynurenine and acetylkynurenine.

$\dagger$ Anthranilic acid and anthranilic glucuronide.

Since the quantitative excretion of the various metabolites showed considerable variation, especially in the 24-hour period after tryptophan, an attempt was made to relate the excretion to the body weight. An example of the regression analyses for 3-indoleacetic acid and xanthurenic acid is shown in Figures 2 and 3 . The linear increase in metabolite excretion before tryptophan loading with increasing body weight is apparent for both of these metabolites in children and adults. In the 24-hour period after tryptophan, a relationship is also noted when the 3 -indoleacetic acid data are plotted, although the individual values at any given weight range show some variation. Because of the much higher excretion of metabolites of the kynurenine pathway by the adult females (vide infra), a correlation between weight and excretion of xanthurenic acid after loading is apparent only if their values are excluded from the analysis (Figure 3 ). Similar curves could be constructed with data obtained for other metabolites of the kynurenine pathway. The relatively wide variation of the individual values, the small number of subjects, and the narrow range of the adult weights make it difficult to relate the excretion rate to the weight of the subjects within either the adult male or female groups.

In the preload period the excretion (micromoles per 24 hours per kilogram) of 3-hydroxyanthranilic acid was higher in children than in adult

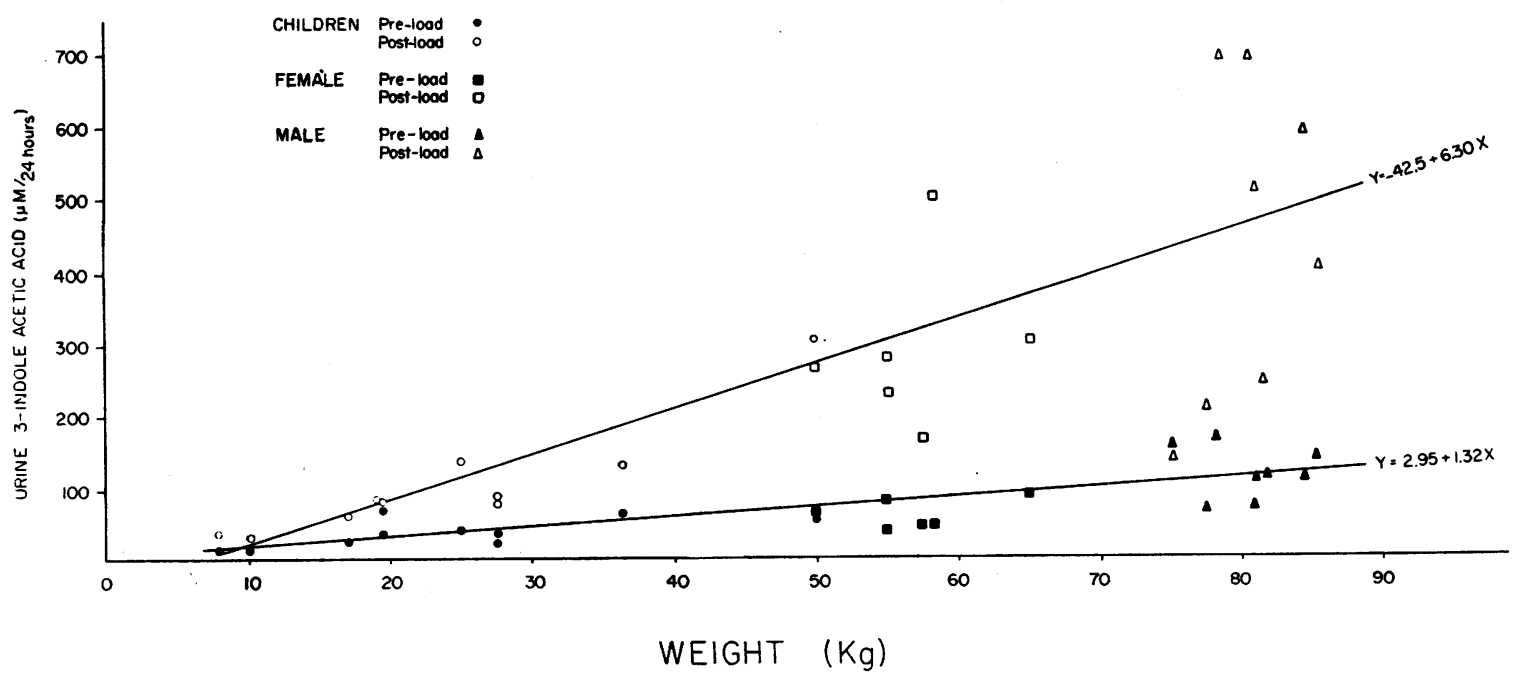

Fig. 2. LINEAR REgReSSION LINE COMPUTED FOR THE 24-HOUR 3-INDOLEACETIC ACID EXCRETION BEFORE AND AFTER TRYPTOPHAN LOADING IN CHILDREN, ADULT FEMALES, AND ADULT MALES. 


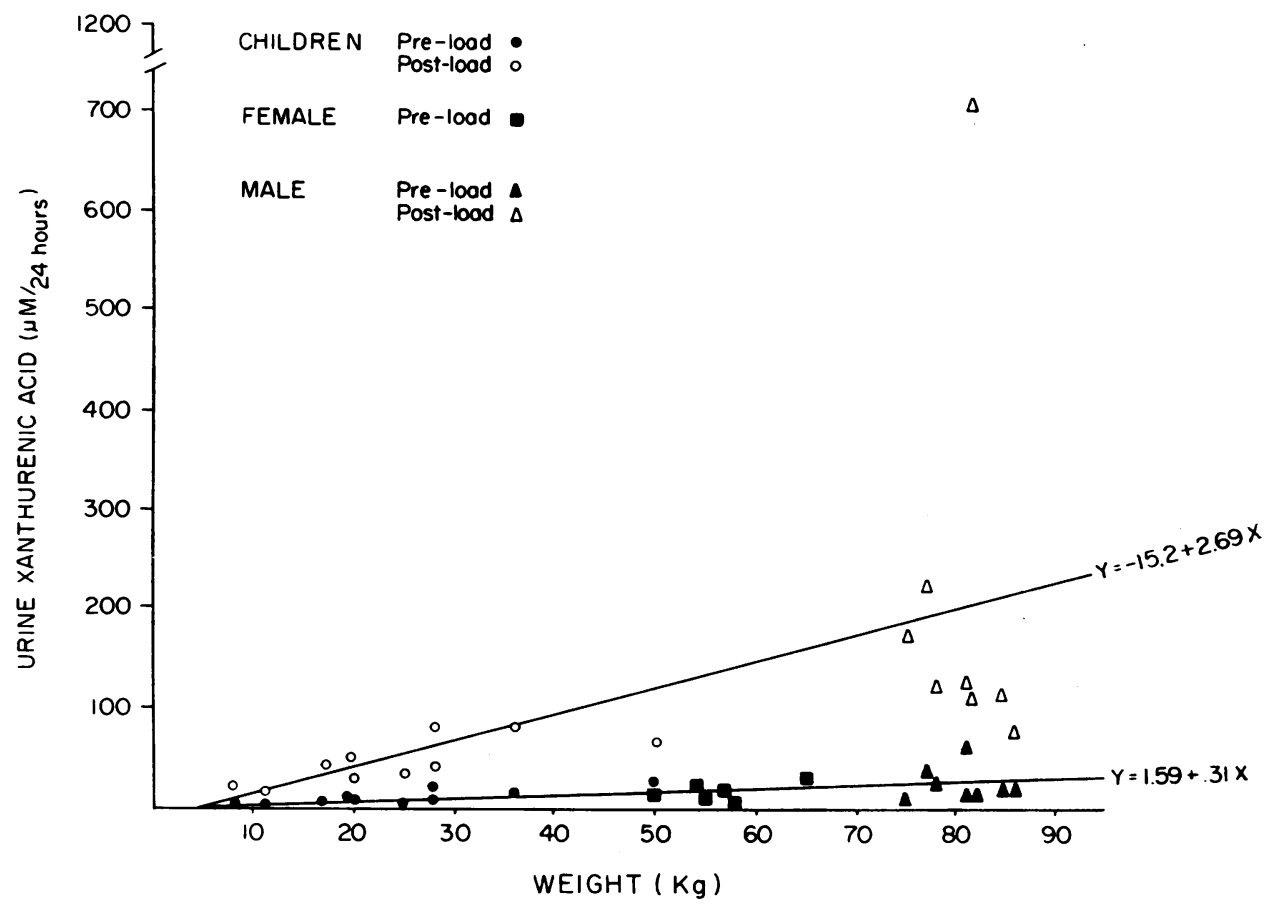

Fig. 3. LINEAR REGRESSION IINE CALCULATED FOR 24-HOUR URINARY EXCRETION OF XANTHURENIC ACID BEFORE TRYPTOPHAN LOADING IN CHILDREN, AdULT FEMALES, AND AdULT MALES. The adult female data are excluded from the analyses in the 24-hour period after tryptophan.

males $(p<0.005)$ and females $(p=0.01)$, whereas the excretion of anthranilic acid was higher in the adult females than in the adult males $(p=0.025)$ or children $(0.01<p<0.025)$. There was no difference, however, in the excretion of other metabolites before tryptophan administration in the three groups. In the postload period the excretion (micromoles per 24 hours per kilogram) of kynurenine and acetylkynurenine, 3-hydroxykynurenine, 3-hydroxyanthranilic acid, anthranilic acid and glucuronide, kynurenic acid, and xanthurenic acid was significantly higher $(p<0.025$ to 0.0005$)$ in the adult $f e$ males than in the adult males or children (Table V). These differences were not seen when the post-tryptophan values of the adult males were

TABLE V

Statistical analysis ( $t$ test) of the metabolite excretion in micromoles per kilogram in the 24-hour period after oral tryptophan

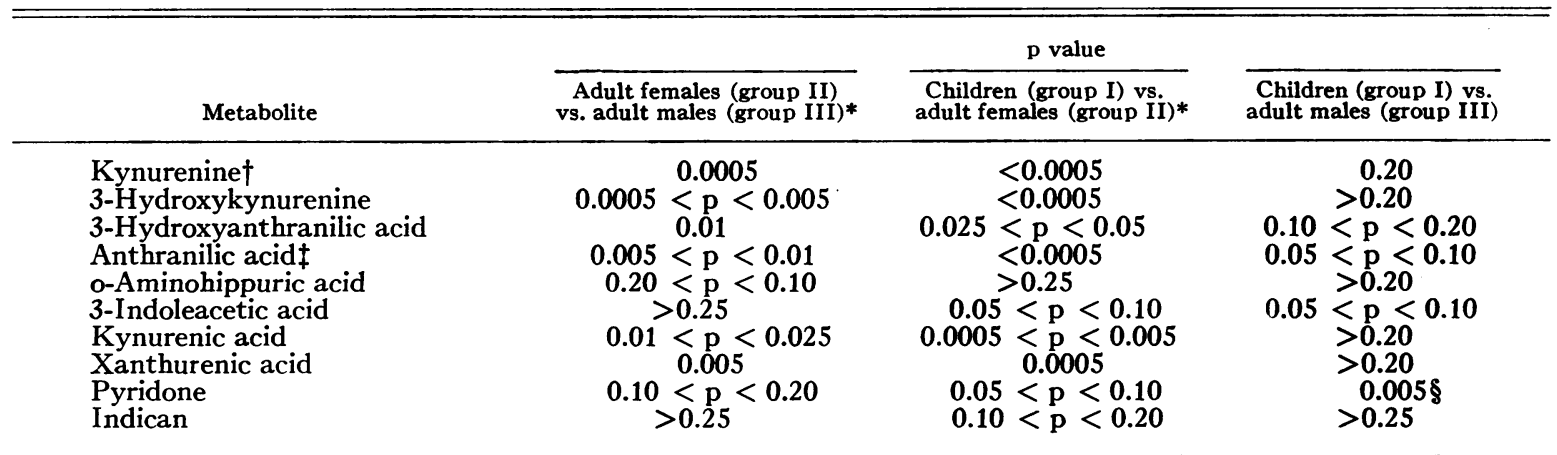

* All significant differences indicate higher excretion in the adult females than in the adult males or children.

$\dagger$ Kynurenine and acetylkynurenine.

I Anthranilic acid and glucuronide.

$\$$ Higher excretion in the children than the adult males. 
TABLE VI

The conversion of oral tryptophan to 11 urinary metabolites excreted in the 24 hours after oral L-tryptophan (100 mg per kg)*

\begin{tabular}{|c|c|c|c|}
\hline Group & $\begin{array}{l}\text { Dose of oral } \\
\text { tryptophan }\end{array}$ & $\begin{array}{c}\text { Urinary } \\
\text { metabolites } \\
\text { excreted in } 24 \\
\text { hours after } \\
\text { tryptophan }\end{array}$ & $\begin{array}{l}\text { Per cent of } \\
\text { tryptophan } \\
\text { excreted as } \\
\text { metabolites } \\
\text { measured }\end{array}$ \\
\hline $\begin{array}{l}\text { Group I } \\
\text { (children) }\end{array}$ & umoles & umoles & $\%$ \\
\hline $\begin{array}{l}\text { D.M. } \\
\text { M.K. } \\
\text { C.C. } \\
\text { S.S. } \\
\text { P.D. } \\
\text { S.N. } \\
\text { G.A. } \\
\text { L.G. } \\
\text { K.L. } \\
\text { A.H. }\end{array}$ & $\begin{array}{r}24,500 \\
17,600 \\
13,200 \\
12,200 \\
12,200 \\
8,910 \\
9,110 \\
8,420 \\
10,900 \\
4,830\end{array}$ & $\begin{array}{r}1,750 \\
991 \\
505 \\
500 \\
801 \\
543 \\
192 \\
701 \\
335 \\
201\end{array}$ & $\begin{array}{l}7.14 \\
5.60 \\
3.81 \\
4.08 \\
6.54 \\
6.08 \\
2.10 \\
8.31 \\
3.05 \\
4.16\end{array}$ \\
\hline $\begin{array}{l}\text { Mean } \\
\text { SD }\end{array}$ & & & $\begin{array}{l}5.09 \\
1.96\end{array}$ \\
\hline
\end{tabular}

Group II

(adult female)

$\begin{array}{lrrc}\text { C.M. } & 24,500 & 3,458 & 14.1 \\ \text { J.N. } & 24,500 & 4,753 & 19.4 \\ \text { R.B. } & 26,900 & 3,703 & 13.7 \\ \text { M.P. } & 28,400 & 4,248 & 15.0 \\ \text { A.R. } & 38,200 & 5,650 & 14.8 \\ \text { D.D. } & 26,400 & 3,068 & 11.6 \\ & & & \\ \text { Mean } & & 4,147 & 14.8 \\ \text { SD } & & 946 & 2.57\end{array}$

Group III

(adult male)

$\begin{array}{lccc}\text { R.R. } & 42,100 & 1,337 & 3.17 \\ \text { S.M. } & 36,700 & 2,192 & 5.98 \\ \text { J.S. } & 36,700 & 2,700 & 7.36 \\ \text { W.P. } & 36,700 & 5,606 & 15.3 \\ \text { H.L. } & 36,700 & 2,663 & 7.25 \\ \text { K.D. } & 37,700 & 1,574 & 4.17 \\ \text { B.J. } & 38,200 & 2,019 & 5.28 \\ \text { K.B. } & 39,200 & 1,344 & 3.43 \\ & & & \\ \text { Mean } & & 2,429 & 6.49 \\ \text { SD } & & 1,391 & 3.89\end{array}$

* Statistical analysis (Student's distribution) of 1) per cent tryptophan excreted as metabolites measured: adult males vs. adult females, $p<0.0005$; children vs. adult females, $p<0.0005$; adult males vs. children, $0.10<p$ $<0.20$; and 2 ) total urinary metabolites excreted in 24 hours after tryptophan: adult males vs. adult females, $\mathrm{p}=0.01$.

$\dagger$ The total amount of measured metabolites excreted in the 24 hours preceding L-tryptophan was subtracted from the total amount of metabolites excreted in the 24 hours after L-tryptophan. The metabolites measured were acetylkynurenine, 3-hydroxyanthranilic acid, kynurenine, 3-hydroxykynurenine, anthranilic acid and glucuronide, o-aminohippuric acid, 3-indoleacetic acid, kynurenic acid, xanthurenic acid, and pyridones.

$\ddagger$ Per cent $=$ [urinary metabolites excreted after tryptophan (micromoles) $\times 100] /$ tryptophan dose (micromoles). compared with those of the children. The only difference between the latter two groups was the higher excretion of pyridone in the child. No differences in excretion of these metabolites were noted between male and female children.

2) Conversion of L-tryptophan to urinary metabolites. The percentage of the oral L-tryptophan excreted as 11 urinary metabolites in the 24-hour period after loading is shown in Table VI. This was calculated by subtracting the 11 metabolites (excluding indican) excreted in the preload period from those excreted in the 24-hour period after tryptophan. This percentage was $5.09 \pm$ 1.96 for children, $6.49 \pm 3.89$ for adult males, and $14.8 \pm 2.57$ for adult females. The percentage did not bear any direct relationship to the age, surface area, or body weight of the subject. The percentage of conversion for the adult females is statistically higher than that of the adult males and the children $(p<0.0005)$, although there is no difference between the latter two groups. One adult male (W.P.), however, excreted $15.3 \%$ of the tryptophan as urinary metabolites, whereas the remaining adult males excreted 3.17 to $7.36 \%$ of the administered tryptophan. The reason for the high excretion in this one subject is unknown. Although the adult females as a group received a smaller amount of tryptophan, the 24-hour quantitative excretion of the total urinary metabolites was higher in the female group $(4,147 \pm 946$ $\mu$ moles) than in the adult male group $(2,429 \pm$ 1,391) $(\mathrm{p}=0.01)$.

The excretion of each metabolite expressed as the percentage of the administered load is shown in Table VII. Higher values $(p<0.025$ to 0.0005 ) were obtained in women than in children or men for kynurenine (including acetylkynurenine), 3-hydroxykynurenine, 3-hydroxyanthranilic acid, anthranilic acid and glucuronide, xanthurenic acid, and kynurenic acid. The conversion to 3 -indoleacetic acid was slightly lower in the children $(p=0.025$ to 0.05$)$ than in the adult men and women. The percentage of conversion of tryptophan to the various metabolites was otherwise similar in adult men and children. There was no difference in the conversion between male and female children.

5-HIAA represented 0.017 to $0.090 \%$ of the administered tryptophan and 0.31 to $1.34 \%$ of 
TABLE VII

The conversion of L-tryptophan to urinary metabolites in the 24 hours after oral loading

\begin{tabular}{|c|c|c|c|c|c|c|}
\hline \multirow[b]{3}{*}{ Metabolite } & \multicolumn{6}{|c|}{ Excreted metabolite expressed as per cent of administered tryptophan* } \\
\hline & \multicolumn{2}{|c|}{$\begin{array}{l}\text { Group I } \\
\text { (children) }\end{array}$} & \multicolumn{2}{|c|}{$\begin{array}{c}\text { Group II } \\
\text { (adult females) }\end{array}$} & \multicolumn{2}{|c|}{$\underset{\text { (adult males) }}{\text { Group III }}$} \\
\hline & Mean & $\mathrm{SD}$ & Mean & SD & Mean & $\mathrm{SD}$ \\
\hline & \multicolumn{2}{|c|}{$\%$} & \multicolumn{2}{|c|}{$\%$} & \multicolumn{2}{|c|}{$\%$} \\
\hline Kynureninet & 1.09 & 0.53 & 5.05 & 1.74 & 1.63 & 1.39 \\
\hline 3-Hydroxykynurenine & 0.64 & 0.40 & 2.82 & 0.92 & 1.06 & 1.14 \\
\hline 3-Hydroxyanthranilic acid & 0.61 & 0.38 & 1.28 & 0.43 & 0.63 & 0.48 \\
\hline Anthranilic acidf & 0.13 & 0.09 & 0.74 & 0.29 & 0.33 & 0.22 \\
\hline o-Aminohippuric acid & 0.10 & 0.09 & 0.14 & 0.17 & 0.076 & 0.026 \\
\hline Kynurenic acid & 0.72 & 0.28 & 1.92 & 1.12 & 0.94 & 0.47 \\
\hline Xanthurenic acid & 0.31 & 0.14 & 2.04 & 1.50 & 0.49 & 0.53 \\
\hline 3-Indoleacetic acid & 0.47 & 0.27 & 0.86 & 0.41 & 0.84 & 0.60 \\
\hline Pyridones & 1.00 & 1.03 & 0.59 & 0.56 & 0.49 & 0.26 \\
\hline
\end{tabular}

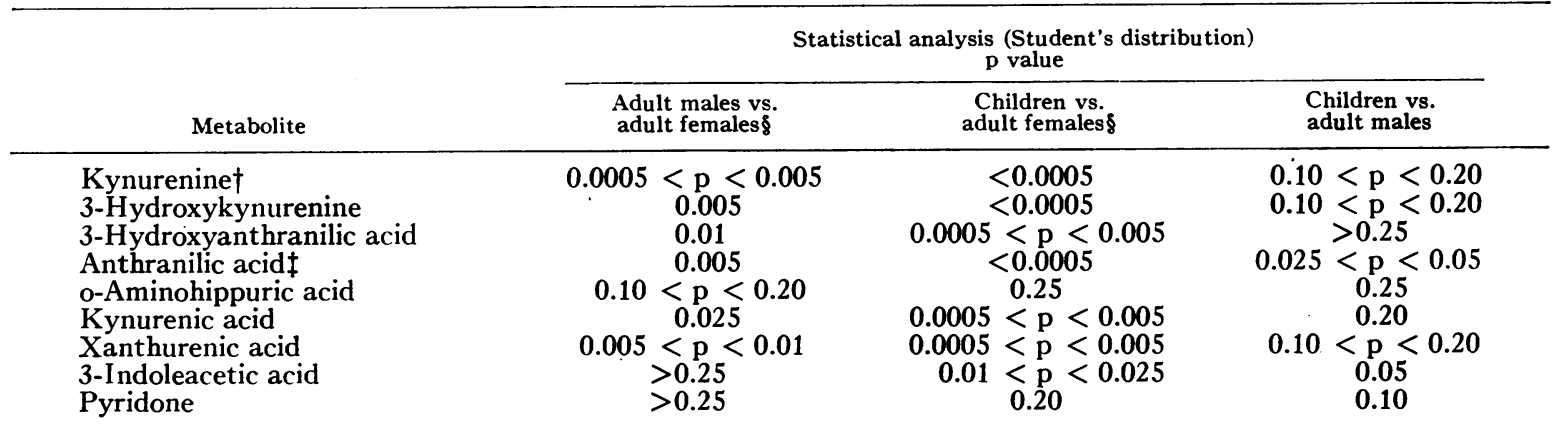

* The excreted metabolite is the difference between the amount excreted in the 24 hours before tryptophan and the amount excreted in the 24 hours after. Per cent $=$ [excreted metabolite (micromoles) $\times 100] /$ tryptophan dose (micromoles).

$\dagger$ Kynurenine and acetylkynurenine.

$\ddagger$ Anthranilic acid and glucuronide.

All significant differences ( $p$ of 0.01 or less) indicate higher conversion in the adult females than in the adult males or children.

the metabolites measured in five children in whom females and two adult males (group IV) were also it was measured.

3) Acetylkynurenine and kynurenine excretion for acetylkynurenine and kynurenine. This group in adult males and females. Nine additional adult was combined with groups II and III to evaluate

TABLE VIII

Comparison of the excretion of kynurenine (including acetylkynurenine) in adult males and females in the 24-hour period after oral tryptophan

\begin{tabular}{|c|c|c|c|c|c|c|c|c|c|c|}
\hline \multirow[b]{3}{*}{ Gioup } & \multirow[b]{3}{*}{ Sex } & \multirow[b]{3}{*}{ No. } & \multirow{3}{*}{$\begin{array}{c}\text { Mean } \\
\text { weight }\end{array}$} & \multirow{3}{*}{$\begin{array}{l}\text { Dose of } \\
\text { tryptophan }\end{array}$} & \multicolumn{6}{|c|}{ Kynurenine and acetylkynurenine excretion } \\
\hline & & & & & \multirow[b]{2}{*}{ Mean } & \multirow[b]{2}{*}{ SD } & \multirow[b]{2}{*}{ Mean } & \multirow[b]{2}{*}{ SD } & \multicolumn{2}{|c|}{$\begin{array}{l}\text { Per cent of } \\
\text { administered } \\
\text { tryptophan* }\end{array}$} \\
\hline & & & & & & & & & Mean & SD \\
\hline & & & $\mathrm{kg}$ & $m g / k g$ & \multicolumn{2}{|c|}{ umoles/24 hours } & \multicolumn{2}{|c|}{$\mu$ moles $/ \mathrm{kg} / 24$ hours } & $\%$ & $\%$ \\
\hline A & $\mathrm{F}$ & 6 & 69.7 & $\begin{array}{l}\text { mean, } 72 \\
\text { range, } 58-87\end{array}$ & 1,188 & 367 & 16.9 & 3.99 & 4.79 & 1.49 \\
\hline$\stackrel{\mathrm{B}}{\mathrm{C}}$ & $\begin{array}{l}\mathrm{F} \\
\mathrm{M}\end{array}$ & $\begin{array}{r}9 \\
10\end{array}$ & $\begin{array}{l}57.4 \\
80.8\end{array}$ & 100 & $\begin{array}{r}1,285 \\
680\end{array}$ & $\begin{array}{l}548 \\
453\end{array}$ & $\begin{array}{c}22.3 \\
8.48\end{array}$ & $\begin{array}{l}9.31 \\
5.60\end{array}$ & $\begin{array}{l}4.66 \\
1.71\end{array}$ & $\begin{array}{l}2.03 \\
1.24\end{array}$ \\
\hline \multicolumn{11}{|c|}{ Statistical analysis (Student's distribution) } \\
\hline \multicolumn{4}{|c|}{$\begin{array}{l}\text { Group A vs. group C } \\
\text { Group B vs. group C }\end{array}$} & & \multicolumn{2}{|c|}{$\begin{aligned} 0.01 & <\mathrm{p}<0.025 \\
0.005 & <\mathrm{p}<0.01\end{aligned}$} & \multicolumn{2}{|c|}{$\begin{aligned} 0.0005<p & <0.005 \\
p & =0.0005\end{aligned}$} & \multicolumn{2}{|c|}{$\begin{array}{l}\mathrm{p}<0.0005 \\
\mathrm{p}=0.0005\end{array}$} \\
\hline
\end{tabular}

* Per cent $=[($ micromoles excreted in 24 hours postload $)-($ micromoles excreted in 24 hours preload $)] /$ tryptophan load (micromoles). 


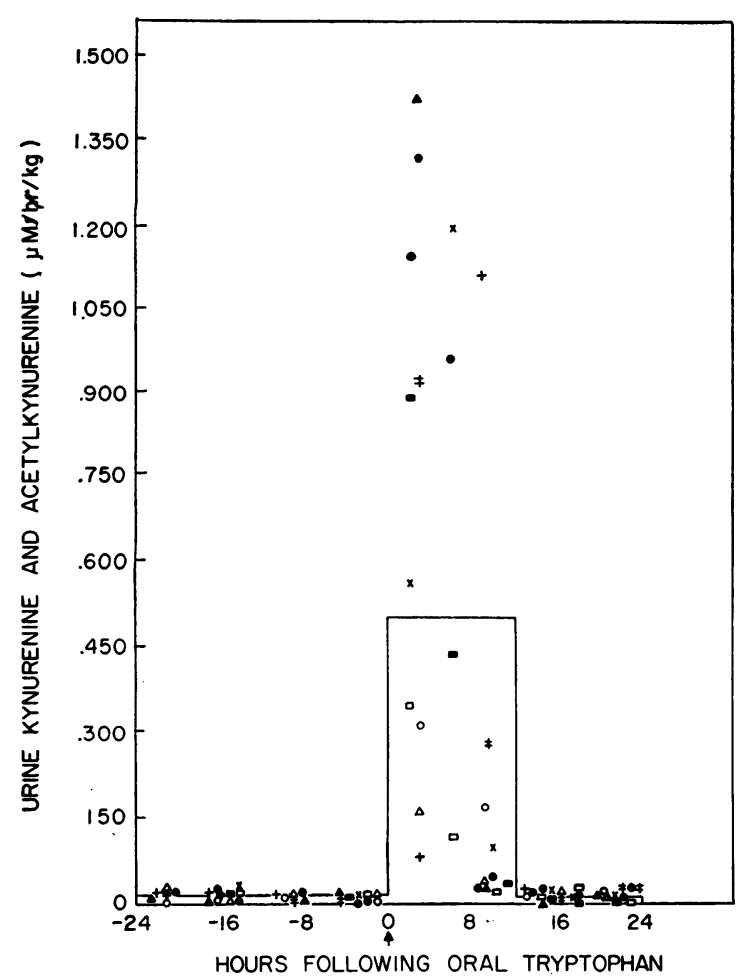

Fig. 4. Sequential URinary EXCRetion of KyNUReNINE AND ACETYLKYNURENINE BEFORE AND AFTER ORAL TRYPTOPHAN IN TEN CHILDREN. The horizontal line indicates the mean excretion rate.

more completely the excretion of these metabolites in a larger group of subjects. This composite group was then evaluated on the basis of the dose of tryptophan used. The results are tabulated for

TABLE IX

The mean urinary excretion rate of tryptophan metabolites 24 hours before and 12 hours after oral L-tryptophan in ten control children (group I)

\begin{tabular}{|c|c|c|c|c|}
\hline \multirow[b]{2}{*}{ Metabolite } & \multicolumn{2}{|c|}{$\begin{array}{c}\text { 24-hour } \\
\text { period before } \\
\text { tryptophan }\end{array}$} & \multicolumn{2}{|c|}{$\begin{array}{l}\text { 12-hour } \\
\text { period after } \\
\text { tryptophan }\end{array}$} \\
\hline & Mean & $\mathrm{SD}$ & Mean & SD \\
\hline & \multicolumn{4}{|c|}{$\mu$ moles $/$ hour $/ \mathrm{kg}$} \\
\hline Kynurenine* & 0.013 & 0.005 & 0.503 & 0.237 \\
\hline 3-Hydroxykynurenine & 0.046 & 0.009 & 0.327 & 0.148 \\
\hline 3-Hydroxyanthranilic acid & 0.065 & 0.023 & 0.351 & 0.167 \\
\hline Anthranilic acid $\dagger$ & 0.006 & 0.003 & 0.090 & 0.063 \\
\hline o-Aminohippuric acid & 0.007 & 0.003 & 0.049 & 0.033 \\
\hline Kynurenic acid & 0.013 & 0.006 & 0.322 & 0.100 \\
\hline Xanthurenic acid & 0.016 & 0.007 & 0.132 & 0.063 \\
\hline Pyridones & 0.174 & 0.180 & 0.408 & 0.232 \\
\hline 3-Indoleacetic acid & 0.070 & 0.031 & 0.280 & 0.092 \\
\hline Indican & 0.265 & 0.125 & 0.324 & 0.173 \\
\hline
\end{tabular}

* Kynurenine and acetylkynurenine.

† Anthranilic acid and anthranilic glucuronide. kynurenine and acetylkynurenine in Table VIII. Six adult females (group A) received a tryptophan load of 58 to $87 \mathrm{mg}$ per $\mathrm{kg}$ (mean, $72 \mathrm{mg}$ per $\mathrm{kg}$ ) ; nine females (group B) were given 100 mg per $\mathrm{kg}$; and ten adult males (group C) received $100 \mathrm{mg}$ per $\mathrm{kg}$ of tryptophan. Groups A and $\mathrm{B}$ had a higher excretion (micromoles per kilogram per 24 hours) of kynurenine (including acetylkynurenine) than group $\mathrm{C}$ ( $\mathrm{p}$ of 0.005 and 0.0005 , respectively). The mean percentage of conversion of tryptophan to kynurenine was 4.79 \pm 1.49 for group A and $4.66 \pm 2.03$ for group B. These values were statistically higher $(p=0.0005)$ than for group $\mathrm{C}(1.71 \pm 1.24 \%)$. The observed

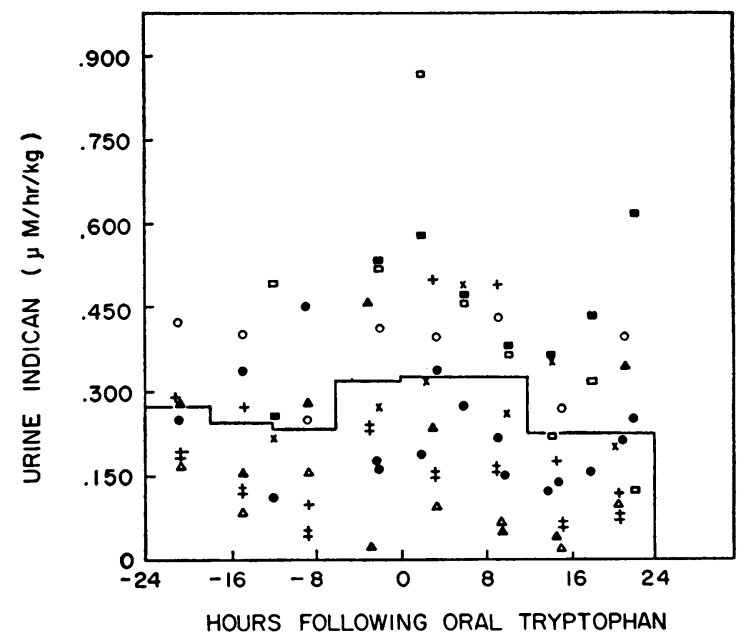

Fig. 5. Sequential URINARY EXCRETION OF INDiCAN BEFORE AND AFTER ORAL TRYPTOPHAN IN TEN CHILDREN. The horizontal line indicates the mean excretion rate. Note the lack of increase in urinary indican excretion.

(uncorrected) excretion in groups A and B was similar but was higher than group $C$ ( $p$ of less than 0.025 and 0.01 , respectively). Although women in group A weighed more than those in group $\mathrm{B}$ and were given a smaller amount of tryptophan ( 58 to $87 \mathrm{mg}$ per $\mathrm{kg}$ ), the percentage of conversions and the observed excretion were similar. This suggests that a higher amount of tryptophan given to group A might have resulted in an even greater quantitative excretion.

4) Sequential analysis of urinary metabolites after L-tryptophan loading (100 $\mathrm{mg}$ per $\mathrm{kg}$ ) in children. The urinary excretion rates of 12 tryptophan metabolites (kynurenine, acetylkynurenine, anthranilic acid and glucuronide, 3-hydroxy- 

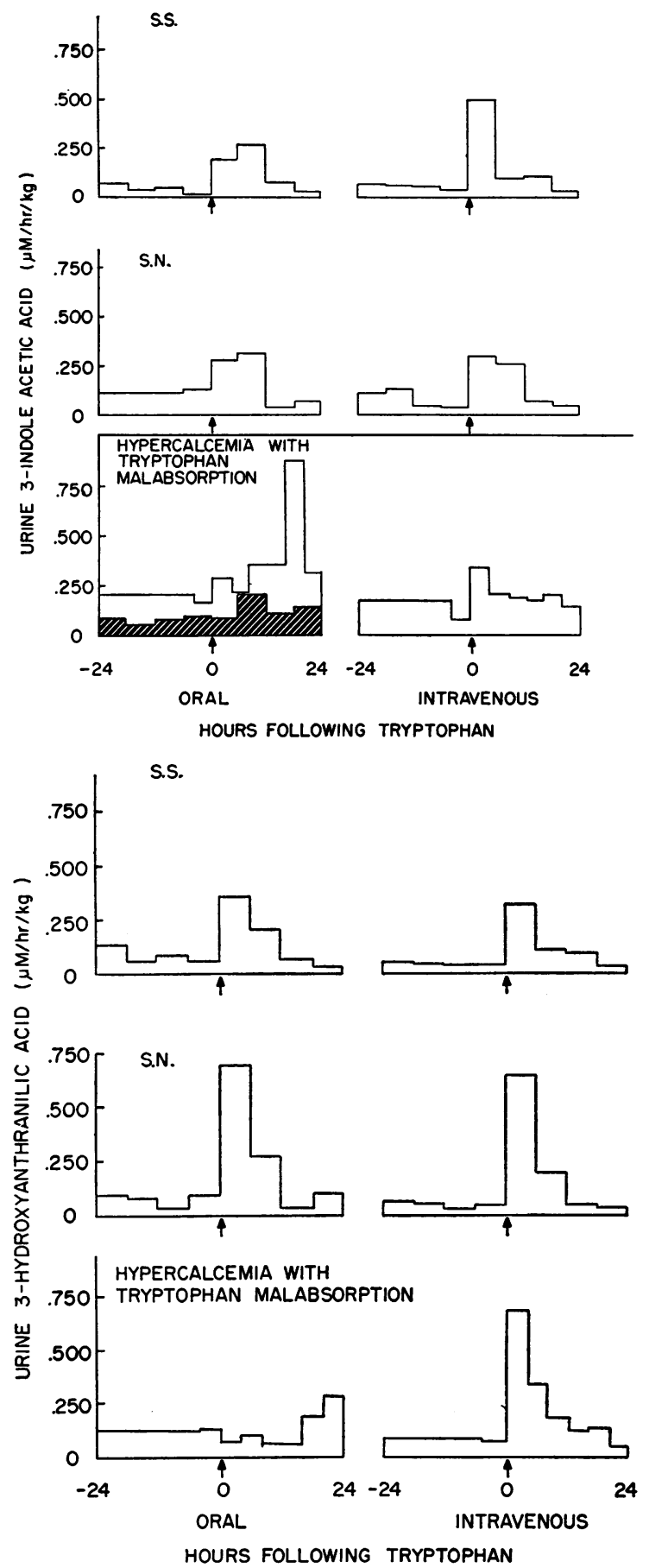

Fig. 6. UPPER: ChANGeS IN THE URINARY EXCRETION RATE OF 3-INDOLEACETIC ACID BEFORE AND AFTER ORAL AND INTRAVENOUS TRYPTOPHAN IN TWO NORMAL CHILDREN (S.S. AND S.N.) AND IN A PATIENT WITH TRYPTOPHAN MALABSORPTION. The hatched area refers to studies done after treatment with neomycin. The late 3-indoleacetic acid rise in the patient is abolished by neomycin and is not seen after intravenous tryptophan. Lower: CHANGES
TABLE $X$

Comparison of the 24-hour urinary excretion of 11 tryptophan metabolites after oral and intravenous tryptophan (100 $\mathrm{mg}$ per $\mathrm{kg}$ ) in a normal child (S.S.)

\begin{tabular}{lcc}
\hline \hline & \multicolumn{2}{c}{$\begin{array}{c}\text { Excreted metabolite expressed } \\
\text { as per cent of total } \\
\text { metabolites measured* }\end{array}$} \\
\cline { 2 - 3 } \multicolumn{1}{c}{ Metabolite } & Oral & iv \\
\hline Kynurenine† & $\%$ & $\%$ \\
3-Hydroxykynurenine & 5.53 & 7.00 \\
3-Hydroxyanthranilic acid & 7.32 & 4.85 \\
Anthranilic acid $\ddagger$ & 10.4 & 8.62 \\
O-Aminohippuric acid & 2.54 & 2.35 \\
Kynurenic acid & 1.55 & 2.43 \\
Xanthurenic acid & 10.3 & 9.50 \\
Pyridones & 6.66 & 7.05 \\
3-Indoleacetic acid & 44.10 & 45.8 \\
& 11.6 & 12.4 \\
\hline
\end{tabular}

* The excreted metabolite is determined by subtracting the amount of the metabolite excreted in the 24-hour period preceding oral tryptophan from the amount excreted in the 24 hours after the load.

$\dagger$ Kynurenine and acetylkynurenine.

$\ddagger$ Anthranilic acid and anthranilic glucuronide.

kynurenine, 3-hydroxyanthranilic acid, 3-indoleacetic acid, pyridone, o-aminohippurate, kynurenic acid, xanthurenic acid, and indican) were determined in 4- to 6-hour periods for 24 hours after the administration of L-tryptophan in the ten children. Figure 4 depicts in graphic form the excretion rate in micromoles per kilogram per hour of kynurenine and acetylkynurenine. Except for indican and pyridone, the responses of ten of the metabolites were similar: the increase in the excretion rate reached a maximum within 6 to 12 hours and returned to preload values within 12 hours after the load, so that the urinary metabolites attributable to the administered tryptophan were excreted within 12 hours. Although the temporal response was similar, there was wide variation in the amplitude of excretion rates. Since the urinary excretion of these metabolites after tryptophan had returned to preload values after 12 hours, a comparison of the excretion rate during this period of time with that preceding the load might reflect more appropriately the actual magnitude of response (Table IX). There was no

IN THE URINARY EXCRETION RATE OF 3-HYDROXYANTHRANILIC ACID BEFORE AND AFTER ORAL AND INTRAVENOUS TRYPTOPHAN. Note the similarity in response between the two loads in each normal child (S.S. and S.N.). A normal response is seen in the patient only after intravenous tryptophan. 
significant increase in the mean indican output in the ten children (Figure 5). Pyridone output showed considerable variation in responses and in seven children was excreted in amounts considerably higher than preload values up to 24 hours after the load.

5) Comparison of oral and intravenous L-tryptophan. L-Tryptophan was administered intravenously to three children (S.N., S.S., K.L.). In each child the oral and intravenous tryptophan induced similar quantitative responses. Table $\mathrm{X}$ illustrates a comparison of the intravenous and oral loads in a normal child (S.S.). The kinetic responses after the loads by either route of administration were also similar for each of the tryptophan derivatives measured (Figure 6). This type of response is different from that observed in a patient with tryptophan malabsorption and hypercalcemia $(20,21)$. In this disease a much greater excretion in kynurenine-pathway metabolites is seen after intravenous loading than after oral tryptophan. In addition, 3-indoleacetic acid and indican are excreted in increased amounts 16 to 20 hours after oral tryptophan; this late rise is due to the action of intestinal bacteria on unabsorbed tryptophan and may be prevented by steri- lization of the intestinal tract. If urine samples were collected in 24-hour periods rather than every 6 hours, this abnormality would be missed.

6) Tryptophan in the stool. Paper chromatography of the carmine-stained stool collected after oral tryptophan administration in three children failed to reveal tryptophan by Ninhydrin reagent. However, staining of these chromatograms for indoles with Ehrlich's reagent revealed the presence of small amounts of tryptophan. ${ }^{3}$ Random stool specimens from seven normal subjects processed and stained in a similar manner revealed similar results. In two instances tryptamine and 3-indoleacetic acid were also present.

Effect of tryptophan on serum calcium level. In 8 of 14 normal subjects there was a significant increase in serum calcium after oral tryptophan (Figure 7). This was initially observed after two different loads in the patient with tryptophan malabsorption and led to the calcium determinations in the normal subjects. In most instances, the hypercalcemia was apparent between 8 and 36 hours after the load.

${ }^{3}$ In this laboratory, Ehrlich's stain of paper chromatograms can detect 0.001 to $0.002 \mu$ moles of tryptophan; this is ten times more sensitive than Ninhydrin reagent.

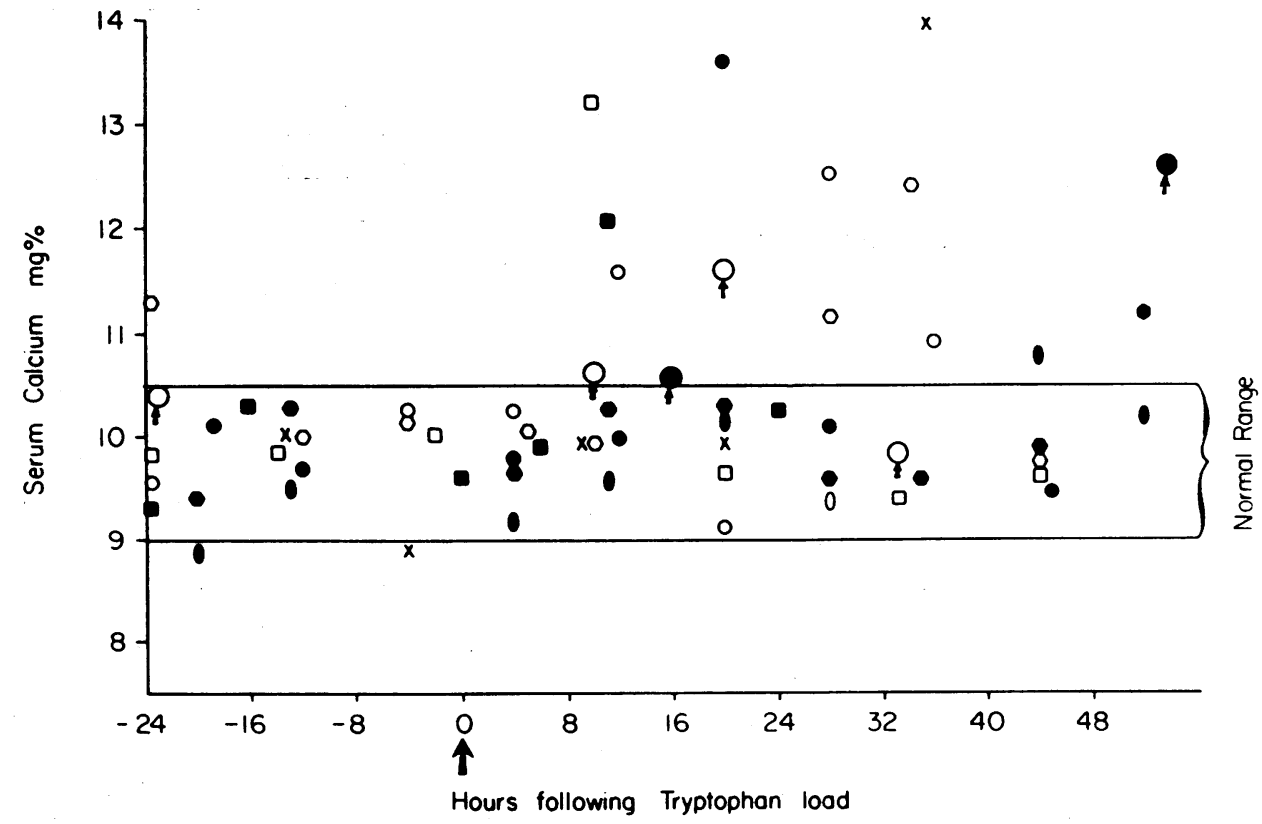

Fig. 7. Changes in serum calcium after oral tryptophan (100 Mg Per KG) IN eight NORMAL CHILDREN. The arrows indicate the values after two loads in the patient with tryptophan malabsorption. 


\section{Discussion}

Studies of the quantitative excretion of tryptophan metabolites have been reported by a number of investigators $(6,7,9-15,23,26,33-36)$. Comparison of these results with those obtained in our study is difficult because of differences in the experimental design. Subjects have been given DL- or L-tryptophan in absolute quantities independent of size or in doses calculated according to body weight. For example, Price (7) and Marver (10) administered $2 \mathrm{~g}$ of L-tryptophan, Boyland and Williams (11) gave $10 \mathrm{~g}$ of DL-tryptophan, and other workers have administered L-tryptophan in a dose varying from 30 to 100 $\mathrm{mg}$ per $\mathrm{kg}$. In addition, some studies have not correlated observed results with such parameters as body weight, sex, or age of the subject.

Direct comparison of results obtained in the present study, utilizing a dose of tryptophan of $100 \mathrm{mg}$ per $\mathrm{kg}$, with the studies of Price and Brown (7, 9, 35-37), using $2.0 \mathrm{~g}$ of tryptophan in adults, reveals a higher excretion in our study. This discrepancy would appear to be due to the difference in the amount of tryptophan administered. Methods other than ion exchange chromatography have also been used for the quantitative measurement of these metabolites (33). O'Brien and Groshek (13), using paper chromatographic methods (33) to analyze the 7-hour urine specimens collected after a tryptophan load of $100 \mathrm{mg}$ per $\mathrm{kg}$ in mentally defective children, obtained results for some of the metabolites within the general range of the current study. Using similar methods and the same dose of tryptophan (100 mg per $\mathrm{kg}$ ), Vassella, Hellström, and Wengle (34) interpreted their results in infants as showing a higher excretion of kynurenine than that recorded by other investigators in adults in whom a lower dose of tryptophan per unit of body weight was given. However, comparison of their results with the current investigation, where the same amount of tryptophan per unit of body weight was given, reveals no differences between infants and older children or adult males.

The dose of tryptophan used in this investigation was $100 \mathrm{mg}$ per $\mathrm{kg}$ of body weight. In normal adults the excretion of various tryptophan metabolites increases after a load of 9.8 mmoles $(2.0 \mathrm{~g})$, and larger amounts of tryptophan re- sult in greater excretion $(7,23)$. Since it has been shown that tryptophan in a dose of $30 \mathrm{mg}$ per $\mathrm{kg}$ does not increase 5-hydroxyindoleacetic acid excretion (3), a dose of $100 \mathrm{mg}$ per $\mathrm{kg}$, which does result in an increased excretion of this metabolite, may be needed to stress the other pathways involved in the metabolism of tryptophan.

During the preload periods, the excretion rates (micromoles per 24 hours per kilogram) of the various tryptophan metabolites were similar in the children, adult males, and adult females. The only demonstrable differences were the higher 3-hydroxyanthranilic acid excretion in the children and the higher anthranilic acid excretion in the adult females. After an oral tryptophan load of $100 \mathrm{mg}$ per $\mathrm{kg}$, there was a significantly higher excretion (micromoles per 24 hours per kilogram) of kynurenine (including acetylkynurenine), 3-hydroxykynurenine, 3-hydroxyanthranilic acid, anthranilic acid, xanthurenic acid, and kynurenic acid in adult females than in adult males or children. There was also a significantly higher percentage of tryptophan converted to each of these metabolites. No such differences were seen between male and female children or between adult males and children. The percentage of tryptophan excreted as the 11 metabolites measured was 5.09 \pm 1.96 in the children, $6.49 \pm 3.89$ in the adult males, and $14.8 \pm 2.57$ in the adult females. The percentage in the female group was significantly higher $(p=0.0005)$ than in the other two groups. In the males the percentage of excretion agrees with that obtained by Price and Brown $(7,23)$ in the adult male given similar amounts of tryptophan, although 3-indoleacetic acid and 3-hydroxykynurenine were not included in his data.

Although the women weighed less than the men and hence received a smaller dose of tryptophan, the total urinary metabolites excreted were significantly higher than in the adult males. When kynurenine and acetylkynurenine were evaluated alone in a larger group of women and men, the observed urinary excretion and percentage of conversion of tryptophan to these metabolites were significantly higher in the women. Indeed, these differences were still apparent when women were given an average dose of tryptophan of $72 \mathrm{mg}$ per $\mathrm{kg}(5.0 \mathrm{~g})$ and the men received $100 \mathrm{mg}$ per $\mathrm{kg}(8.0 \mathrm{~g})$.

The reason for these differences after trypto- 
phan loading is not apparent. They have not been previously reported, although Marver (10) has indicated that there is a suggestion of slightly higher values in women given a smaller dose of tryptophan. Although only five female and five male children were investigated in the present study, there were no apparent differences between these two groups. Of interest is the fact that the higher excretion in the adult females was not observed before the tryptophan load. The absence of reported differences in the period after tryptophan in other studies may be related to the higher dose we administered, which may have permitted maximal stress to the biochemical mechanisms and enzyme systems involved in tryptophan degradation.

That xanthurenic acid excretion increases during pregnancy has been known for some time (38). Brown, Thornton, and Price (39) have shown that basal levels of kynurenine, 3-hydroxykynurenine, and pyridone increase during pregnancy. After $2 \mathrm{~g}$ of tryptophan there was a higher than normal increase in these metabolites as well as acetylkynurenine and xanthurenic acid; kynurenic acid and o-aminohippuric acid did not increase excessively. Administration of pyridoxine resulted in a decrease in the levels of these metabolites after tryptophan loading, although the levels of kynurenine, 3-hydroxykynurenine, and pyridone were still higher than normal. Tryptophan loads administered to women at various times during the menstrual cycle revealed as the only change a decrease in the postmenstrual 3-hydroxykynurenine response. These investigators concluded that these biochemical observations were best explained on the basis of vitamin $B_{6}$ deficiency as well as some hormonal influence.

In our study, the excretion of kynurenine pathway metabolites after tryptophan (100 $\mathrm{mg}$ per $\mathrm{kg}$ ) was higher in women than in men or children. The findings of Brown and his associates indicate that these same metabolites, in addition to pyridone, are higher in pregnant than in nonpregnant women after $2 \mathrm{~g}$ of tryptophan, approximately one-third the amount used in the current investigation. The difference that becomes apparent during pregnancy is probably also present in the nonpregnant female but requires a larger dose of tryptophan for its expression.

These differences may be due to variations in enzyme activity between the sexes-a situation that has been shown to exist with other enzymes (40). Hormonal induction of enzymes has been exemplified by the demonstration of estrogen induction of certain dehydrogenases involved in steroid metabolism in the rat $(41-43)$, as well as testosterone induction of esterase isozyme in the mouse (44). Tryptophan pyrrolase, which catalyzes the first reaction in the metabolism of tryptophan, was originally demonstrated by Knox and Mehler to be adaptively controlled (45). This substrate induction of tryptophan pyrrolase in rat liver has been studied extensively by Greengard and Feigelson $(46,47)$, who showed that tryptophan allows the apoenzyme to become more completely saturated with the porphyrin-containing coenzyme and thus protects the enzyme against inhibition. Adrenal steroids such as hydrocortisone have also been shown to increase tryptophan pyrrolase activity (48-50). Although insulin and testosterone give a similar response, the synthetic nonsteroid estrogen, diethylstilbestrol, has no effect on the enzyme in rat liver (51). The mechanism of hormonal induction of this enzyme is uniquely different from that of substrate induction (52, 53). Both processes are inhibited by puromycin, an inhibitor of protein synthesis, whereas only the cortisone-mediated increase in enzyme activity is inhibited by actinomycin $\mathrm{D}$, an inhibitor of RNA synthesis (54). Whether or not the differences described in the current investigation are related to variations in hormonal enzyme induction cannot be answered at present.

Although the serotonin pathway is considered to be an important avenue in the metabolism of tryptophan, the 5-HIAA excretion after the load accounted for only $1 \%$ of the total measured metabolites. This agrees with a previous study suggesting that a dose of tryptophan of $100 \mathrm{mg}$ per $\mathrm{kg}$ is needed to achieve an increased urinary excretion of 5-HIAA (3).

Urinary indican is derived from the action of intestinal bacteria containing tryptophanase on tryptophan to form indole, which is absorbed and conjugated in the liver to form the sulfated esters of indoxyl (indican). No increase in indican excretion was demonstrated in normal subjects after oral tryptophan. In addition, paper chromatography of stool specimens obtained after the load revealed no tryptophan by Ninhydrin stain 
and trace amounts by Ehrlich's stain. Similar findings were obtained with random stool specimens. Comparison of oral and intravenous loads in the same subject reveals similar quantitative excretion and kinetic responses. These observations suggest that tryptophan administered orally in a dose of $100 \mathrm{mg}$ per $\mathrm{kg}$ may be completely absorbed from the intestinal tract. These findings are consistent with the observations of Langner and Edmonds (55), who demonstrated complete absorption of tryptophan from the upper intestine of the rat. Since the amount of tryptophan given to the human subject was considerably in excess of that normally ingested in the diet and apparently this larger amount was completely absorbed, some doubt exists as to whether or not indoles and indican are derived from tryptophan that has reached the distal bowel without being absorbed. Christensen, Feldman, and Hastings $(56,57)$ have shown that active transport of amino acids may be bidirectional in the rat intestine. Tryptophan secretion into the gut, therefore, may be an important source of indole and indican.

The kinetics of the excretion in children after tryptophan reveal that the derivatives are excreted within 12 hours and that the peak excretion occurs in most instances within 4 to 6 hours. This was true of all the metabolites of the kynurenine pathway except pyridone, which was excreted in increased amounts for up to 24 hours after loading. A response similar to that of the kynurenine metabolites was observed with 3 -indoleacetic acid, a finding previously documented by Weissbach and co-workers (3) and Milne, Crawford, Girão, and Loughridge (58). Although the excretion of this compound may be decreased by inhibiting intestinal bacterial growth, the kinetics of the response suggest that the immediate excretory rise is due to enzymatic activity located in tissue (3).

The comprehensive approach to the metabolism of tryptophan that has been discussed in detail above was utilized in the delineation of a familial disease characterized by infantile hypercalcemia with nephrocalcinosis and excessive indicanuria $(20,21)$. A high fasting urinary excretion of indican and 3 -indoleacetic acid was present; 16 to 24 hours after oral tryptophan a rise was seen in both of these compounds. Indeed, there was a preferential shunting of tryptophan metabolism to indican and indoleacetic acid (including indolelactic acid and indoleacetamide) that accounted for $60 \%$ of metabolites excreted after oral loading, even though the percentage of tryptophan converted to urinary metabolites as a whole was normal. That this was due to a specific defect in the intestinal transport of tryptophan is suggested by the following observations: a decrease in the urinary excretion and obliteration of the late rise of indoleacetic acid and indican by pretreatment with neomycin; the presence of large amounts of tryptophan in the stool; a much greater increase in excretion of metabolites of the kynurenine pathway after intravenous tryptophan than after oral tryptophan-a difference not seen in normal subjects; and absence of the late rise in indican and indoleacetic acid after intravenous tryptophan.

The biochemical abnormalities in this patient bear many similarities to those described by Milne and associates in Hartnup's disease $(58,59)$. This disease is characterized by defective renal tubular and intestinal transport of tryptophan, aminoaciduria, and indicanuria; a late rise in indoleacetic acid and indican also occurs after oral tryptophan.

In phenylketonuria excessive indole excretion (60) and indicanuria (61) have also been described. By this method of analysis, one of our children with untreated phenylketonuria revealed an increase in the excretion of indican 18 to 24 hours after an oral tryptophan load (28). This was not seen on a phenylalanine-free diet or after intravenous loading. High levels of indoleacetic acid were also present. An excessive amount of tryptophan could be demonstrated in the stool. These findings support the concept that in phenylketonuria, tryptophan may be incompletely absorbed from the intestinal tract, the indole derivative arising in part from the action of intestinal bacteria on unabsorbed tryptophan.

The relationship of the metabolic abnormality in the patient with tryptophan malabsorption to the hypercalcemia has not been completely defined. However, the administration of tryptophan in a dose of $100 \mathrm{mg}$ per $\mathrm{kg}$ induced transient hypercalcemia in this patient and in 50\% of the children investigated. In addition, phosphorus reabsorption may be specifically inhibited in the renal tubule by certain L-amino acids including tryptophan (62-64). 


\section{Summary}

1. The metabolism of tryptophan was comprehensively studied in children and adult males and females.

2. The urinary excretion (micromoles per 24 hours per kilogram) of tryptophan metabolites in men, women, and children is similar during preload periods. After oral administration of tryptophan (100 mg per $\mathrm{kg}$ ), a higher percentage of tryptophan was excreted as urinary metabolites in women $(14.8 \pm 2.57)$ than in men (6.49 \pm $3.89)$ or children $(5.09 \pm 1.90)$. This was due to a much higher quantitative excretion of metabolites of the kynurenine pathway in adult females: kynurenine and acetylkynurenine, 3-hydroxykynurenine, 3-hydroxyanthranilic acid, anthranilic acid and glucuronide, kynurenic acid, and xanthurenic acid. Differences between children and adult males were not seen. No differences in 3-indoleacetic acid or indican excretion were observed in the three groups.

3. Kinetic studies in children indicate that there occurs a prompt increase in excretion rate followed by return to normal rate within 12 hours for ten of the metabolites. Although the temporal responses of individuals were similar, the quantitative excretion rate showed considerable variation. Intravenous and oral tryptophan administration in the same subjects resulted in similar quantitative excretion rates and percentage of tryptophan conversion.

4. These studies suggest that tryptophan is completely absorbed from the upper intestinal tract and raise the possibility that indole and indican formation may result from secretion of tryptophan at an intestinal site.

5. The value of this method of analysis is i1lustrated by the demonstration of certain abnormalities in tryptophan metabolism due to defective intestinal absorption of this amino acid.

6. A relationship between tryptophan and calcium and phosphorus metabolism is also documented.

\section{Acknowledgments}

We are grateful to Dr. Constance van Eeden of the Department of Biostatistics for her advice on the statistical analysis and to Dr. Robert Ulstrom of the Department of Pediatrics for reviewing the manuscript.

\section{References}

1. Gholson, R. K., L. V. Hankes, and L. M. Henderson. 3-Hydroxyanthranilic acid as an intermediate in the oxidation of the indole nucleus of tryptophan. J. biol. Chem. 1962, 235, 132.

2. Gholson, R. K., Y. Nishizuka, A. Ichiyama, H. Kawai, S. Nakamura, and O. Hayaishi. New intermediates in the catabolism of tryptophan in mammalian liver. J. biol. Chem. 1962, 237, 2043.

3. Weissbach, H., W. King, A. Sjoerdsma, and S. Udenfriend. Formation of indole-3-acetic acid and tryptamine in animals. J. biol. Chem. 1959, 234, 81.

4. Gooder, H., and F. C. Happold. The tryptophanasetryptophan reaction. The nature of the enzymeco-enzyme-substrate complex. Biochem. J. (Lond.) 1954, 57, 369.

5. Symposium on Tryptophan Metabolism. Division of Medicinal Chemistry, American Chemical Society. Atlantic City, N. J., September 14, 1959.

6. Brown, R. R. Studies on the metabolism of tryptophan in man. Rec. chem. Progr. 1961, 22, 29.

7. Price, J. M. Disorders of tryptophan metabolism. Univ. Mich. med. Bull. 1958, 24, 461.

8. Florentino, R. F., and W. N. Pearson. Effect of threonine-induced amino acid imbalance on the excretion of tryptophan metabolites by the rat. J. Nutr. 1962, 78, 101.

9. Price, J. M., R. R. Brown, and H. A. Peters. Tryptophan metabolism in porphyria, schizophrenia, and a variety of neurologic and psychiatric diseases. Neurology (Minneap.) 1959, 9, 456.

10. Marver, H. S. Studies on tryptophan metabolism: 1. Urinary tryptophan metabolites in hypoplastic anemias and other hematologic disorders. J. Lab. clin. Med. 1961, 58, 425.

11. Boyland, E., and D. C. Williams. The metabolism of tryptophan: 2. The metabolism of tryptophan in patients suffering from cancer of the bladder. Biochem. J. 1956, 64, 578.

12. Jérôme, H., J. LeJeune, and R. Turpin. Etude de l'excrétion urinaire de certains métabolites du tryptophan chez les enfants mongoliens. C. R. Acad. Sci. (Paris) 1960, 251, 474.

13. O'Brien, D., and A. Groshek. The abnormality of tryptophane metabolism in children with mongolism. Arch. Dis. Childh. 1962, 37, 17.

14. Abul-Fadl, M. A. M., and A. S. Khalafallah. Studies on the urinary excretion of certain tryptophan metabolites in bilharziasis and its possible relation to bladder cancer in Egypt. Brit. J. Cancer 1961, $15,479$.

15. Hellström, B., and F. Vassella. Tryptophan metabolism in infantile spasm. Acta paediat. (Uppsala) 1962, 51, 665.

16. Quagliariello, E., F. Tancredi, C. Saccone, and M. Piazza. Interrelation hetween tryptophan and 
nicotinic acid in human viral hepatitis. Nature (Lond.) 1962, 194, 976.

17. Piazza, M., and F. Tancredi. Tryptophan-nicotinic acid metabolism in subjects recently or long since recovered from viral hepatitis. Nature (Lond.) 1963, 197, 903.

18. Oka, M., and V. V. E. Leppänen. Metabolism of tryptophan in diabetes mellitus. Acta med. scand. 1963, 173, 361.

19. Bett, I. M. Effect of pyridoxine on tryptophan metabolism in rheumatoid arthritis. Ann. rheum. Dis. 1962, 21, 388.

20. Michael, A. F., K. N. Drummond, R. A. Ulstrom, and R. A. Good. The blue diaper syndrome: familial hypercalcemia of infancy associated with abnormal tryptophan metabolism (abstract). Amer. J. Dis. Child. 1962, 104, 510.

21. Drummond, K. N., A. F. Michael, R. A. Ulstrom, and R. A. Good. The blue diaper syndrome: familial hypercalcemia with nephrocalcinosis and indicanuria. Description of a new familial disease with definition of metabolic abnormality. Amer. J. Med., in press.

22. Smith, I. Chromatographic and Electrophoretic Techniques. New York, Interscience, 1960, vol. 1.

23. Brown, R. R., and J. M. Price. Quantitative studies on metabolites of tryptophan in the urine of the dog, cat, rat, and man. J. biol. Chem. 1956, 219, 985.

24. Tompsett, S. L. 3-Hydroxykynurenine in human urine. Clin. chim. Acta 1960, 5, 415.

25. Brown, R. R. The isolation and determination of urinary hydroxykynurenine. J. biol. Chem. 1957, 227, 649.

26. Tompsett, S. L. The determination in urine of some metabolites of tryptophan-kynurenine, anthranilic acid and 3-hydroxyanthranilic acid-and reference to the presence of $\mathrm{O}$-aminophenol in urine. Clin. chim. Acta 1959, 4, 411.

27. Satoh, K., and J. M. Price. Fluorometric determination of kynurenic acid and xanthurenic acid in human urine. J. biol. Chem. 1958, 230, 781.

28. Michael, A. F., K. N. Drummond, and D. Doeden. Unpublished observations.

29. Price, J. M. The determination of N-methyl-2pyridone-5-carboxamide in human urine. J. biol. Chem. 1954, 211, 117.

30. Udenfriend, S., E. Titus, and H. Weissbach. The identification of 5-hydroxy-3-indoleacetic acid in normal urine and a method for its assay. J. biol. Chem. 1955, 216, 499.

31. Meiklejohn, A. P., and F. P. Cohen. The quantitative determination of indoxyl compounds in urine. J. Lab. clin. Med. 1942, 27, 949.

32. Berry, H. Personal communication.

33. Coppini, D., C. A. Benassi, and M. Montorsi. Quantitative determination of tryptophan metabolites (via kynurenine) in biologic fluids. Clin. Chem. 1959, 5, 391.
34. Vassella, F., B. Hellström, and B. Wengle. Urinary excretion of tryptophan metabolites in the healthy infant. Pediatrics 1962, 30, 585.

35. Brown, R. R. Tryptophan Metabolism in Man. Symposium on Tryptophan Metabolism. Division of Medicinal Chemistry, American Chemical Society, Atlantic City, N. J., September 14, 1959.

36. Price, J. M., R. R. Brown, J. G. Rukavina, C. Mendelson, and S. A. M. Johnson. Scleroderma (acrosclerosis) : II. Tryptophan metabolism before and during treatment by chelation (EDTA). J. invest. Derm. 1957, 29, 289.

37. Price, J. M. Some effect of chelating agents in tryptophan metabolism in man. Fed. Proc. 1961, 20 (suppl. 10), 223.

38. Sprince, H., R. S. Lowy, C. E. Folsome, and J. S. Behrman. Studies on the urinary excretion of "xanthurenic" acid during normal and abnormal pregnancy: a survey of the excretion of "xanthurenic" acid in normal non-pregnant, normal pregnant, pre-eclamptic, and eclamptic women. Amer. J. Obstet. Gynec. 1951, 62, 84.

39. Brown, R. R., M. J. Thornton, and J. M. Price. The effect of vitamin supplementation on the urinary excretion of tryptophan metabolites by pregnant women. J. clin. Invest. 1961, 40, 617.

40. Knox, W. E., V. H. Auerbach, and E. C. C. Lin. Enzymatic and metabolic adaptations in animals. Physiol. Rev. 1956, 36, 164.

41. Rubin, B. L. Sex differences in orientation of reduction products of 3 -keto- $\mathrm{C}_{10}$ steroids by rat liver homogenates. J. biol. Chem. 1957, 227, 917.

42. Ryan, K. J., R. A. Meigs, Z. Petro, and G. Morrison. Estrogen-induced 16-hydroxysteroid dehydrogenase activity in rat kidney. Science 1963, 142, 243.

43. Yates, F. E., A. L. Herbst, and J. Urquhart. Sex difference in rate of ring $A$ reduction of $\Delta^{4}-3$-ketosteroids in vitro by rat liver. Endocrinology 1958, 63, 887.

44. Shaw, C. R., and A. L. Koen. Hormone-induced esterase in mouse liver. Science 1963, 140, 70.

45. Knox, W. E., and A. H. Mehler. The adaptive increase of the tryptophan peroxidase-oxidase system of liver. Science 1951, 113, 237.

46. Greengard, O., and P. Feigelson. The purification and properties of liver tryptophan pyrrolase. J. biol. Chem. 1962, 237, 1903.

47. Feigelson, P., and O. Greengard. Regulation of liver tryptophan pyrrolase activity. J. biol. Chem. 1962, 237, 1908.

48. Geschwind, I. I., and C. H. Li. Endocrine control of an induced hepatic enzyme system (abstract). J. clin. Endocr. 1954, 14, 789.

49. Thomson, J. F., and E. T. Mikuta. The effect of cortisone and hydrocortisone on the tryptophan peroxidase-oxidase activity of rat liver. Endocrinology 1954, 55, 232. 
50. Knox, W. E., and V. H. Auerbach. The hormonal control of tryptophan peroxidase in the rat. J. biol. Chem. 1955, 214, 307.

51. Schor, J., and E. Frieden. Induction of tryptophan peroxidase of rat liver by insulin and alloxan. J. biol. Chem. 1958, 233, 612.

52. Civen, M., and W. E. Knox. The independence of hydrocortisone and tryptophan inductions of tryptophan pyrrolase. J. biol. Chem. 1959, 234, 1787.

53. Knox, W. E. The adaptive control of tryptophan and tyrosine metabolism in animals. Trans. N. Y. Acad. Sci. 1963, 25, 503.

54. Greengard, O., M. A. Smith, and G. Acs. Relation of cortisone and synthesis of ribonucleic acid to induced and developmental enzyme formation. J. biol. Chem. 1963, 238, 1548.

55. Langner, R. R., and E. J. Edmonds. Absorption studies on tryptophan and acetyltryptophan. J. biol. Chem. 1956, 223, 583.

56. Christensen, H. N., and B. H. Feldman. Reversibility of intestinal transport (abstract). Fed. Proc. 1963, 22, 418.

57. Christensen, H. N., B. H. Feldman, and A. B. Hastings. Concentrative and reversible character of intestinal amino acid transport. Amer. J. Physiol. 1963, 205, 255.

58. Milne, M. D., M. A. Crawford, C. B. Girão, and L. W. Loughridge. The metabolic disorder in Hartnup disease. Quart. J. Med. 1960, 29, 407.

59. Asatoor, A. M., J. Craske, D. R. London, and M. D. Milne. Indole production in Hartnup disease. Lancet 1963, 1, 126.

60. Armstrong, M. D., and K. S. Robinson. On the excretion of indole derivatives in phenylketonuria. Arch. Biochem. 1954, 52, 287.

61. Bessman, S. P., and K. Tada. Indicanuria in phenylketonuria. Metabolism 1960, 9, 377.

62. Drummond, K. N., and A. F. Michael. Specificity of the inhibition of tubular phosphate reabsorption by certain amino acids. Nature (Lond.) 1964, 201, 1333.

63. Drummond, K. N., and A. F. Michael. Amino acids and phosphate transport: evidence for a common renal tubular mechanism. Society Pediatric Research, Atlantic City, N. J., 1963.

64. Michael, A. F., and K. N. Drummond. Phosphate and amino acid interrelationship in renal tubular transport. Fed. Proc. 1964, 23, 328.

\section{SPECIAL NOTICE TO SUBSCRIBERS}

Post Offices will no longer forward the Journal when you move.

Please notify The Journal of Clinical Investigation, Business Office, 10 Stoughton Street, Boston, Mass. 02118, at once when you have a change of address, and do not omit the Zip Code number. 